Jurnal Sastra Indonesia

\title{
Variasi Fonologi dan Leksikon Bahasa Jawa di Kabupaten Cilacap (Kajian) Geografi Dialek di Perbatasan Jawa-Sunda
}

\author{
Annisa Ul Afidah ${ }^{\bowtie}$, Hari Bakti Mardikantoro \\ Jurusan Bahasa dan Sastra Indonesia, Fakultas Bahasa dan Seni, Universitas Negeri Semarang, \\ Indonesia
}

\section{Info Artikel}

Sejarah Artikel:

Diterima November 2018

Disetujui Mei 2019

Dipublikasikan Juli 2019

\section{Kata kunci:}

variasi fonologis; variasi

leksikon; bahasa Jawa;

geografi dialek.

Keywords:

phonological variations;

lexicon variations; Java

language; dialect geography.

\begin{abstract}
Abstrak
Penelitian ini membahas variasi bahasa Jawa di Kabupaten Cilacap pada tataran fonologi dan leksikon. Titik pengamatan dalam penelitian ini berjumlah 4 yang merupakan daerah-daerah yang berbatasan dengan Kabupaten Pangandaran, Jawa Barat, yaitu Desa Kedungreja, Kecamatan Kedungreja dan Desa Tambakreja, Kecamatan Kedungreja serta Desa Purwodadi dan Desa Rawaapu, Kecamatan Patimuan. Pengumpulan data menggunakan metode pupuan lapangan dan metode cakap. Data-data yang telah terkumpul kemudian dianalisis menggunakan metode padan fonetis artikulatoris dan teknik pilah unsur penentu (teknik PUP) dengan teknik lanjutan yaitu teknik HBB dan teknik HBS. Hasil penelitian menunjukkan bahwa ditemukan variasi bahasa Jawa Cilacap (BJC) berupa variasi fonologi dan leksikon. Variasi fonologi meliputi variasi bunyi vokal dan konsonan serta korespondensi bunyi vokal dan konsonan. Variasi leksikon meliputi gejala onomasiologis dan semasiologis. Data variasi fonologi dan leksikon tersebut selanjutnya disajikan dalam peta bahasa. Faktor-faktor geografis wilayah menjadi akibat munculnya variasi bahasa Jawa di Kabupaten Cilacap, khususnya di wilayah perbatasan Jawa-Sunda.
\end{abstract}

\begin{abstract}
This study discusses the variation of Javanese language in Cilacap Regency at the level of phonology and lexicon. Observation points in this study amounted to 4 which are areas bordering Pangandaran Regency, West Java, namely Kedungreja Village, Kedungreja District and Tambakreja Village, Kedungreja District and Purwodadi Village and Rawaapu Village, Patimuan District. Data collection uses field methods and proficient methods. The data that has been collected is then analyzed using the phonetic articulatory matching method and the technique of determining the determinants (PUP techniques) with advanced techniques, namely HBB techniques and HBS techniques. The results showed that variations in the Cilacap Javanese language (BJC) were found in variations of phonology and lexicon. Phonological variations include variations of vowel and consonant sounds and correspondence of vowel and consonant sounds. The lexicon variation includes onomasiological and semasiological symptoms. The phonological and lexicon variation data are then presented in the language map. The geographical factors of the region were due to the emergence of variations in Javanese language in Cilacap Regency, especially in the Javanese-Sundanese border region.
\end{abstract}

(C) 2019 Universitas Negeri Semarang 


\section{PENDAHULUAN}

Bahasa merupakan salah satu sarana komunikasi yang digunakan dalam kehidupan manusia. Bahasa sebagai suatu sistem lambang bunyi bersifat arbitrer, unik, produktif, dinamis, dan bervariasi (Chaer 2007 : 13). Di Indonesia terdapat berbagai bahasa di setiap daerah. Salah satu bahasa yang masih terjaga kelestariannya sampai saat ini adalah bahasa Jawa. Bahasa Jawa mengalami perkembangan dari masa ke masa (Raymonda dalam Sumarlam 2012 : 114). Kabupaten Cilacap merupakan salah satu daerah yang menggunakan bahasa Jawa untuk berkomunikasi. Perkembangan bahasa dapat dipengaruhi oleh penutur yang menggunakan bahasa itu sendiri. Setiap penutur bahasa memiliki latar belakang sosial yang berbedabeda. Faktor lain yang juga berpengaruh terhadap berkembangnya suatu bahasa yaitu letak geografis suatu daerah.

Kabupaten Cilacap merupakan daerah yang memiliki letak geografis antara $07^{\circ} 45^{\prime}$ Lintang Selatan dan $109^{\circ}$ 02' Bujur Timur. Sebelah utara berbatasan dengan Kabupaten Brebes dan Kabupaten Banyumas, sebelah timur berbatasan dengan Kabupaten Banyumas dan Kabupaten Kebumen, sebelah selatan berbatasan dengan Samudera Hindia, serta sebelah barat berbatasan dengan Kabupaten Pangandaran, Kabupaten Ciamis, dan Kota Banjar, Jawa Barat (cilacapkab.go.id/). Kabupaten Cilacap memiliki 24 kecamatan, yang terdiri atas: (1) Adipala, (2) Binangun, (3) Kroya, (4) Maos, (5) Nusawungu, (6) Sampang, (7) Kesugihan, (8) Jeruklegi, (9) Cilacap Selatan, (10) Cilacap Tengah, (11) Cilacap Utara, (12) Bantasari, (13) Kawunganten, (14) Gandrungmangu, (15) Karang Pucung, (16) Cipari, (17) Kedungreja, (18) Patimuan, (19) Sidareja, (20) Cimanggu, (21) Dayeuhluhur, (22) Majenang, (23) Wanareja, dan (24) Kampung Laut. Bagian utara adalah daerah perbukitan yang merupakan lanjutan dari Rangkaian Puncak Bogor di Jawa Barat sedangkan bagian selatan merupakan dataran rendah. Di bagian utara, timur, dan selatan juga dipenuhi oleh kawasan hutan. Sebagian besar wilayah Cilacap, terutama sebelah selatan juga terdiri atas dataran rendah daerah pesisir pantai. Ibukota Kabupaten Cilacap berada di tepi pantai Samudera Hindia dan wilayahnya juga meliputi bagian timur Pulau Nusa Kambangan.

Bahasa Jawa yang dituturkan oleh masyarakat di Kabupaten Cilacap bervariasi. Penutur bahasa Jawa di Kabupaten Cilacap memiliki latar belakang sosial yang berbedabeda, yang menunjukkan munculnya pelapisan masyarakat, meliputi sistem yang membagi masyarakat ke dalam beberapa lapisan secara bertingkat. Pelapisan dalam masyarakat yang dimaksud antara lain pendidikan, pekerjaan, usia, jenis kelamin, dan sebagainya (Soekanto dalam Zulaeha 2010: 76). Berbatasan langsung dengan Provinsi Jawa Barat, Cilacap juga merupakan daerah pertemuan budaya Jawa Banyumasan dengan budaya Sunda (Priangan Timur). Berkaitan dengan hal ini, masyarakat Kabupaten Cilacap memiliki latar belakang geografis, yaitu letak daerahnya yang berbatasan dengan Kabupaten Pangandaran (Jawa Barat) yang mempengaruhi bahasa Jawa di wilayah perbatasan. Oleh karena itu, sebagian penduduk Kabupaten Cilacap ada yang bertutur dalam bahasa Jawa dialek Banyumas dan dialek Sunda, terutama di kecamatan-kecamatan yang berbatasan dengan Jawa Barat, seperti Kecamatan Patimuan dan Kecamatan Kedungreja.

Letak Kabupaten Cilacap yang strategis sebagai daerah yang berbatasan dengan Jawa Barat membawa pengaruh budaya yang menyebabkan munculnya variasi bahasa Jawa di Kabupaten Cilacap. Variasi bahasa yang menarik perhatian itu terdapat pada tataran fonologi dan leksikon. Hal itulah yang menjadi pertimbangan terhadap penelitian variasi bahasa Jawa yang akan dilakukan di daerah Cilacap, khususnya di wilayah yang berbatasan dengan Jawa Barat.

Penelitian dialektologi di Kabupaten Cilacap telah dilakukan oleh Ningtyas, dkk., (2017), yang membahas inovasi fonetis pada kantung Sunda di wilayah Kecamatan Wanareja, Kabupaten Cilacap. Oleh karena itu, penelitian variasi bahasa Jawa berdasarkan 
kajian geografi dialek di Kabupaten Cilacap perlu dilakukan.

Penelitian ini juga terkait dengan penelitian sebelumnya, yaitu penelitian yang dilakukan Diding Rosyadi (2017), Hanifah Andini (2017), dan Devita Maliana Sari (2018) yang terkait dengan leksikon, serta penelitian Anisa Puji Hastuti (2018) dan Arif Antono (2019) yang terkait dengan fonologi dan leksikal.

\section{METODE}

Pendekatan yang digunakan dalam penelirian ini adalah pendekatan metodologis dan pendekatan teoretis. Pendekatan metodologis terdiri atas pendekatan deskriptif kualitatif sedangkan pendekatan teoretis dalam penelitian terdiri atas pendekatan dialektologi, khususnya geografi dialek. Data dalam penelitian ini yaitu berupa kata atau frasa (bahasa Jawa) yang dituturkan oleh informan di setiap titik pengamatan penelitian yang memiliki variasi. Jadi, dalam penelitian ini, peneliti memberikan kepada informan 200 kosakata dasar Swadesh yang dikembangkan menjadi 300 daftar tanyaan, yang meliputi (a) bagian tubuh, (b) kata ganti, sapaan, dan acuan, (c) sistem kekerabatan, (d) kehidupan desa, masyarakat, dan pekerjaan, (e) rumah dan bagian-bagiannya, (f) peralatan dan perlengkapan, (g) makanan dan minuman, (h) tumbuh-tumbuhan, bagiannya, buah dan hasil olahannya, (i) hewan dan bagiannya, (j) waktu, musim, keadaan alam, benda alam, dan arah, (k) gerak dan kerja (aktivitas), (l) perangai, sifat, warna, (m) penyakit, (n) pakaian dan perhiasan, (o) bilangan dan ukuran, (p) kata tugas, adverbial, dan lain-lain. Adapun sumber data dalam penelitian ini merupakan sumber data lisan yang berupa semua tuturan yang digunakan oleh informan di setiap titik pengamatan. Titik pengamatan dalam penelitian ini berjumlah 4 , yaitu Desa Kedungreja, Kecamatan Kedungreja (TP-1), Desa Tambakreja, Kecamatan Kedungreja (TP-2), Desa Purwodadi, Kecamatan Patimuan (TP-3) serta Desa Rawaapu, Kecamatan Patimuan (TP-4). Titiktitik pengamatan tersebut merupakan wilayah yang berdekatan atau berbatasan dengan Kabupaten Pangandaran, Jawa Barat.

Metode pengumpulan data yang digunakan dalam penelitian ini adalah metode pupuan lapangan. Metode pupuan lapangan merupakan metode pengumpulan data melalui penelitian langsung ke lapangan. Pengumpulan bahan menggunakan dua cara, yaitu (1) pencatatan langsung dan (2) perekaman. Dalam pengumpulan data di lapangan, juga digunakan metode simak dan metode cakap. Sementara teknik lanjutan yang digunakan dalam penelitian ini adalah teknik simak libat cakap dan teknik cakap semuka. Pada tahap analisis data, metode yang digunakan adalah metode padan fonetis artikulatoris dengan teknik pilah unsur penentu (PUP), teknik hubung banding memperbedakan (HBB), dan teknik hubung banding mempersamakan (HBS) sesuai dengan teori yang dikemukakan oleh Sudaryanto (2015).

Hasil analisis data dalam penelitian ini disajikan dengan metode formal dan informal. Penyajian dengan metode formal tersebut digunakan dalam pengolahan data, yaitu penggunaan lambang-lambang fonetis dan tabel pada saat mentranskripsi data leksikon bahasa Jawa Cilacap wilayah perbatasan. Adapun penyajian dengan metode informal digunakan bersama dengan metode formal untuk memaparkan hasil analisis data dengan menggunaka kata-kata biasa.

\section{HASIL DAN PEMBAHASAN}

Variasi Fonologi Bahasa Jawa di Kabupaten Cilacap

Variasi fonologi yang ditemukan dalam Bahasa Jawa BJC meliputi variasi bunyi vokal dan konsonan serta korespondensi bunyi vokal dan konsonan.

\section{Variasi Bunyi Vokal}

Berdasarkan data yang diperoleh, telah ditemukan 23 variasi bunyi vokal BJC, yaitu [a] [J], [i] [a], [i] $\sim \mathrm{e}],[\mathrm{I}] \sim[\mathrm{i}],[\mathrm{u}] \sim[\mathrm{U}],[\mathrm{e}] \sim[\varepsilon]$, $[\varepsilon] \sim[\varnothing],[\varepsilon] \sim[\mathrm{a}],[\varepsilon] \sim[\mathrm{e}],[\varepsilon] \sim[\mathrm{i}],[\varepsilon] \sim[\supset][ə] \sim[\varnothing]$, [ə] [a], [ə] [i], [ə] [u], [o] [u], [o] [ว], [ว] [a], [ग] [u], [ø] [a], [ø] [i], [ø] [ə], [ø] [u] .

Variasi [a] [ग] ditemukan pada gloss 'membawa' [ygawa] menjadi [ฤgəwว]. Bunyi [a] 
cenderung dituturkan semua penutur di TP-1, TP-2, dan TP-3 sedangkan bunyi [ग] di TP-4 .

Variasi [i] [a] ditemukan pada gloss 'atau' [utawi] menjadi [utawa]. Bunyi [i] cenderung dituturkan semua penutur di TP-2 dan TP-3 sedangkan bunyi [a] di TP-1 dan TP-4.

Variasi [i] [e] ditemukan pada gloss 'adik' [aḍi] menjadi [aḍe]. Bunyi [i] cenderung dituturkan semua penutur di TP-1 dan TP-2 sedangkan bunyi [e] di TP-3 dan TP-4.

Variasi [I] [i] ditemukan pada gloss 'benih' [wInih] menjadi [winih]. Bunyi [I] cenderung dituturkan semua penutur di TP -2 sedangkan bunyi [i] di TP-1, TP-3, dan TP-4.

Variasi $[\mathrm{u}] \sim[\mathrm{U}]$ ditemukan pada gloss 'labu' [waluh] menjadi [walUh]. Bunyi [u] cenderung dituturkan semua penutur di TP-1 dan TP-2 sedangkan bunyi [U] di TP-3 dan TP4.

Variasi $[e] \sim[\varepsilon]$ ditemukan pada gloss 'bibir' [lambe] menjadi [lambs]. Bunyi [e] cenderung dituturkan semua penutur di TP-1 dan TP-2 sedangkan bunyi [ $\varepsilon]$ di TP-3 dan TP-4.

Variasi $[\varepsilon] \sim[\varnothing]$ ditemukan pada gloss 'ayah' [bapaks] menjadi [bapak]. Bunyi $[\varepsilon]$ cenderung dituturkan semua penutur di TP-1 dan TP-2 sedangkan bunyi [ø] di TP-3 dan TP-4.

Variasi $[\varepsilon] \sim[a]$ ditemukan pada gloss 'galah' [genter] menjadi [gantar]. Bunyi $[\varepsilon]$ cenderung dituturkan semua penutur di TP-1 dan TP-2 sedangkan bunyi [a] di TP-3 dan TP-4.

Variasi $[\varepsilon] \sim[e]$ ditemukan pada gloss 'betis' [kempol] menjadi [kempol]. Bunyi $[\varepsilon]$ cenderung dituturkan semua penutur di TP-1 dan TP-2 sedangkan bunyi [e] di TP-3 dan TP-4 .

Variasi $[\varepsilon] \sim[i]$ ditemukan pada gloss 'cakar' [ceker] menjadi [coker]. Bunyi $[\varepsilon]$ cenderung dituturkan semua penutur di TP-1 dan TP-2 sedangkan bunyi [i] di TP-3 dan TP-4.

Variasi $[\varepsilon] \sim[\supset]$ ditemukan pada gloss 'ikut' [melu] menjadi [milu]. Bunyi $[\varepsilon]$ cenderung dituturkan semua penutur di TP-1 dan TP-2 sedangkan bunyi [ग] di TP-3 dan TP-4.

Variasi [ə] [ø] ditemukan pada gloss ‘saya' [əñวy] menjadi [ñวy]. Bunyi [ə] cenderung dituturkan semua penutur di TP-1 dan TP-2 sedangkan bunyi [ø] di TP-3 dan TP-4.
Variasi [ə] [a] ditemukan pada gloss 'sebelas' [səwəlas] menjadi [səwəlas]. Bunyi [ə] cenderung dituturkan semua penutur di TP-1 dan TP-2 sedangkan bunyi [a] di TP-3 dan TP-4.

Variasi [ə] [i] ditemukan pada gloss 'menggali' [yəḍuk] menjadi [niḍuk]. Bunyi [ə] cenderung dituturkan semua penutur di TP-1 dan TP-2 sedangkan bunyi [i] di TP-3 dan TP-4.

Variasi $[\ni] \sim[\mathrm{u}]$ ditemukan pada gloss 'menggali' [məḍun] menjadi [muḍun]. Bunyi [ə] cenderung dituturkan semua penutur di TP-1 dan TP-2 sedangkan bunyi [u] di TP-3 dan TP-4.

Variasi [o] [3] ditemukan pada gloss 'akar' [oyod] menjadi [jyod]. Bunyi [o] cenderung dituturkan semua penutur di TP-1, TP-2, dan TP-3 sedangkan bunyi [ग] di TP-4.

Variasi $[\mathrm{o}] \sim[\mathrm{u}]$ ditemukan pada gloss 'dusun' [grombol] menjadi [grumbul]. Bunyi [o] cenderung dituturkan semua penutur di TP-1 dan TP-2 sedangkan bunyi [u] di TP-3 dan TP-4.

Variasi [ग] [a] ditemukan pada gloss 'menggigit' [ñokst] menjadi [ñakst]. Bunyi [ว] cenderung dituturkan semua penutur di TP-1 dan TP-2 sedangkan bunyi [a] di TP-3 dan TP-4.

Variasi [ग] [u] ditemukan pada gloss 'ludah' [iḑ̣h] menjadi [iḍuh]. Bunyi [ग] cenderung dituturkan semua penutur di TP-1 dan TP-2 sedangkan bunyi [u] di TP-3 dan TP-4.

Variasi [ø] [a] ditemukan pada gloss 'perabotan rumah tangga' [prabst] menjadi [parabət]. Bunyi [ø] cenderung dituturkan semua penutur di TP-1 dan TP-2 sedangkan bunyi [a] di TP-3 dan TP-4.

Variasi [ø] [i] ditemukan pada gloss 'ijuk' [duk] menjadi [iduk]. Bunyi [ø] cenderung dituturkan semua penutur di TP-1 dan TP-2 sedangkan bunyi [i] di TP-3 dan TP-4.

Variasi [ø] [ə] ditemukan pada gloss 'embun' [b $b^{\text {h } u n] ~ m e n j a d i ~[ə ~} b^{\text {h } u n] . ~ B u n y i ~[ø] ~}$ cenderung dituturkan semua penutur di TP-1 dan TP-2 sedangkan bunyi [ə] di TP-3 dan TP-4.

Variasi [ø] [u] ditemukan pada gloss 'sudah' [wis] menjadi [uwis]. Bunyi [ø] cenderung dituturkan semua penutur di TP-1 dan TP-2 sedangkan bunyi [ə] di TP-3 dan TP-4.

Variasi Bunyi Konsonan

Ditemukan variasi bunyi konsonan dalam BJC yang berjumlah 16 , meliputi variasi $[\mathrm{r}] \sim[\mathrm{d}]$, 
$[\mathrm{d}] \sim[\mathrm{j}], \quad[\varnothing] \sim[?], \quad[\mathrm{w}] \sim[\varnothing], \quad[\mathrm{b}] \sim[\varnothing], \quad[\mathrm{k}] \sim[\varnothing]$, $[\mathrm{k}] \sim[\mathrm{n}], \quad[\mathrm{m}] \sim[\varnothing], \quad[\mathrm{m}] \sim[\mathrm{p}], \quad[\mathrm{g}] \sim[\mathrm{k}], \quad[\mathrm{k}] \sim[\mathrm{t}]$, $[\varnothing] \sim[\mathrm{n}],[\mathrm{r}] \sim[\mathrm{g}],[\mathrm{k}] \sim[\mathrm{n}],[1] \sim[\varnothing]$, dan $[\mathrm{b}] \sim[\mathrm{m}]$.

Variasi [r] [d] ditemukan pada gloss 'hidung' [iruy] menjadi [iḍu]. Bunyi [r] cenderung dituturkan semua penutur di TP-1 dan TP-2 sedangkan bunyi [ə] di TP-3 dan TP-4.

Variasi [d] [j] ditemukan pada gloss 'jari' [driji] menjadi [jriji]. Bunyi [d] cenderung dituturkan semua penutur di TP-1 dan TP-2 sedangkan bunyi [ə] di TP-3 dan TP-4.

Variasi [ø] [?] ditemukan pada gloss 'mata kaki' [ənt $\left.{ }^{\mathrm{h}} \mathrm{O}\right]$ [ənt $\left.\mathrm{t}^{\mathrm{h}} \mathrm{O}\right]$ menjadi [ənt ${ }^{\mathrm{h}}$?] [ənt ${ }^{\mathrm{h}} \supset$ ?]. Bunyi [ø] cenderung dituturkan semua penutur di TP-1 dan TP-2 sedangkan bunyi [?] di TP-3 dan TP-4.

Variasi $[\mathrm{w}] \sim[\varnothing]$ ditemukan pada gloss 'pusar' [wudəl] menjadi [udəl]. Bunyi [w] cenderung dituturkan semua penutur di TP-1 dan TP-2 sedangkan bunyi [ø] di TP-3 dan TP-4.

Variasi $[\mathrm{b}] \sim[\varnothing]$ ditemukan pada gloss 'panggilan laki-laki remaja' [bujan] menjadi [ujay]. Bunyi $[\mathrm{b}]$ cenderung dituturkan semua penutur di TP-1 dan TP-2 sedangkan bunyi [ø] di TP-3 dan TP-4.

Variasi $[\mathrm{k}] \sim[\varnothing]$ ditemukan pada gloss 'kakek' [kaki] menjadi [aki]. Bunyi [k] cenderung dituturkan semua penutur di TP-1 dan TP-2 sedangkan bunyi [ø] di TP-3 dan TP-4.

Variasi $[\mathrm{k}] \sim[\mathrm{n}]$ ditemukan pada gloss 'ibu' [mamaks] menjadi [mamans]. Bunyi [k] cenderung dituturkan semua penutur di TP-1 dan TP-2 sedangkan bunyi [n] di TP-3 dan TP-4.

Variasi $[\mathrm{m}] \sim[\varnothing]$ ditemukan pada gloss 'halaman belakang' [mburitan] menjadi [buritan]. Bunyi $[\mathrm{m}]$ cenderung dituturkan semua penutur di TP-1 dan TP-2 sedangkan bunyi [ø] di TP-3 dan TP-4.

Variasi $[\mathrm{m}] \sim[\mathrm{p}]$ ditemukan pada gloss 'menjemur' [mems] menjadi [meps]. Bunyi [m] cenderung dituturkan semua penutur di TP-1 dan TP-2 sedangkan bunyi [p] di TP-3 dan TP-4.

Variasi $[\mathrm{g}] \sim[\mathrm{k}]$ ditemukan pada gloss 'rumah di tengah sawah' [gubug] menjadi [gubuk]. Bunyi [g] cenderung dituturkan semua penutur di TP-1 dan TP-2 sedangkan bunyi [p] di TP-3 dan TP-4.
Variasi $[\mathrm{k}] \sim \mathrm{t}]$ ditemukan pada gloss 'kopiah' [kupluk] menjadi [tupluk]. Bunyi [k] cenderung dituturkan semua penutur di TP-1 dan TP-2 sedangkan bunyi [p] di TP-3 dan TP-4.

Variasi [ø] [n] ditemukan pada gloss 'enam' [ənəm] menjadi [nənəm]. Bunyi [ø] cenderung dituturkan semua penutur di TP-1 dan TP-2 sedangkan bunyi [n] di TP-3 dan TP-4.

Variasi $[\mathrm{r}] \sim[\mathrm{g}]$ ditemukan pada gloss 'akan' [arəp] menjadi [agəp]. Bunyi [r] cenderung dituturkan semua penutur di TP-1 dan TP-2 sedangkan bunyi [g] di TP-3 dan TP-4.

Variasi $[\mathrm{k}] \sim[\mathrm{n}]$ ditemukan pada gloss

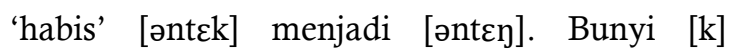
cenderung dituturkan semua penutur di TP-1 dan TP-2 sedangkan bunyi [ $\eta$ ] di TP-3 dan TP-4.

Variasi [1] [ø] ditemukan pada gloss 'sedang' [lagi] menjadi [agi]. Bunyi [1] cenderung dituturkan semua penutur di TP-1 dan TP-2 sedangkan bunyi [ø] di TP-3 dan TP-4 .

Variasi $[\mathrm{b}] \sim[\mathrm{m}]$ ditemukan pada gloss 'supaya' [ben] menjadi [men]. Bunyi [b] cenderung dituturkan semua penutur di TP-1 dan TP-2 sedangkan bunyi [m] di TP-3 dan TP-4

\section{Korespondensi Bunyi Vokal}

Berdasarkan data yang diperoleh, ditemukan 5 kaidah korespondensi bunyi vokal dalam BJC. Kaidah-kaidah korespondensi vokal tersebut di antaranya $[\mathrm{u}] \sim[\mathrm{U}],[\varepsilon] \sim[\mathrm{e}],[\mathrm{o}] \sim[\mathrm{J}]$, [a] [i], dan [a] [0].

$[\mathrm{u}] \sim[\mathrm{U}]$ [ginsul] [ginsUl] 'gigi yang tumbuhnya bertumpuk'

\begin{tabular}{|c|c|c|}
\hline [rambut] & [rambUt] & 'rambut' \\
\hline$[\varepsilon] \sim[e]$ & [kempol] & [kempol] \\
\hline & [tapc] & [tape] \\
\hline
\end{tabular}

[nay] [kenc] [nin] [kene] 'di

$\operatorname{sini}$

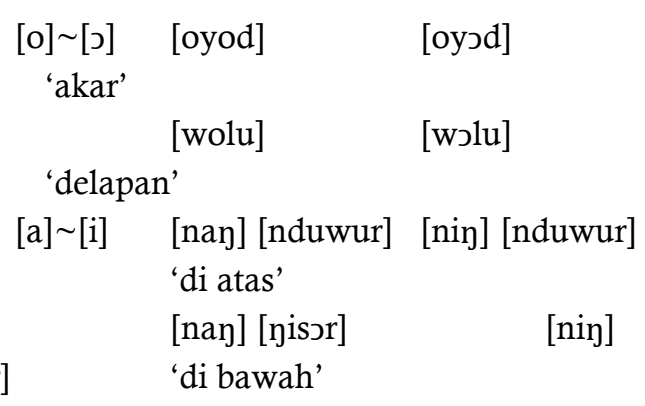




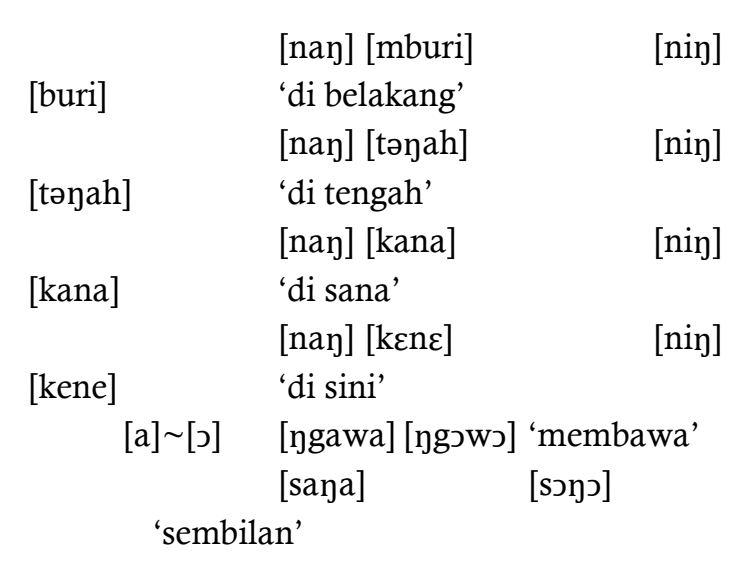

\section{Korespondensi Bunyi Konsonan}

Berdasarkan data yang diperoleh, ditemukan 1 kaidah korespondensi konsonan, yaitu $[\mathrm{m}] \sim[\varnothing]$, yang dirincikan sebagai berikut.

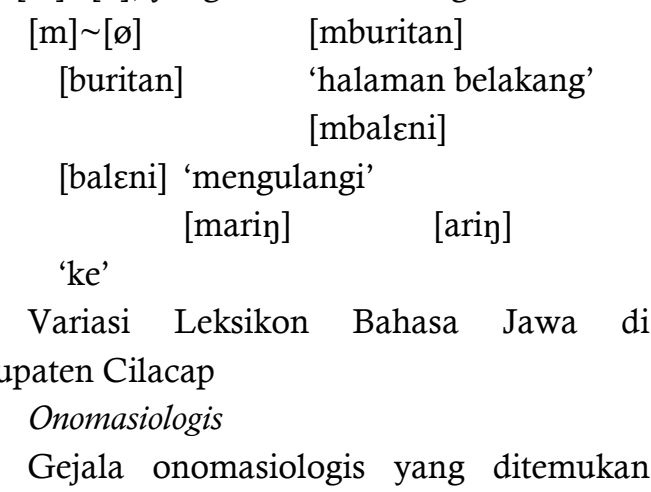
dalam BJC terdapat pada medan makna (1) bagian tubuh, (2) kata ganti, sapaan, dan acuan, (3) sistem kekerabatan, (4) kehidupan desa, masyarakat, dan pekerjaan, (5) rumah dan bagian-bagiannya, (6) peralatan dan perlengkapan, (7) makanan dan minuman, (8) tumbuh-tumbuhan, buah, dan hasil olahannya, (9) hewan dan bagian-bagiannya, (10) waktu, musim, keadaan alam, dan arah, (11) gerak dan kerja, (12) perangai, sifat, dan warna, (13) penyakit, (14) pakaian dan perhiasan, dan (15) kata tugas, adverbial, dan lain-lain.

Pada medan makna bagian tubuh, gejala onomasiologis ditemukan pada gloss 'mulut' yang ditandai dengan leksikon [caykəm] untuk TP-1 dan TP-2 dan [tutuk] untuk TP-3 dan TP4.

Pada medan makna kata ganti, sapaan, dan acuan, gejala onomasiologis ditemukan pada gloss 'kita' yang ditandai dengan leksikon [dewek] di TP-1 dan TP-3, [kit]] di TP-2, dan

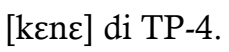

Pada medan makna sistem kekerabatan, gejala onomasiologis ditemukan pada gloss 'anak dari cucu' yang ditandai dengan leksikon [cangah] di TP-1, leksikon [buyut]di TP-2 dan TP-3, dan leksikon [cicit] di TP-4.

Pada medan makna kehidupan desa, masyarakat, dan pekerjaan, gejala onomasiologis ditemukan pada gloss 'datang ke tempat kenduri' yang ditandai dengan leksikon [kənduren] yang cenderung dituturkan oleh semua penutur di TP-1 dan TP-2 dan leksikon [kəpunan] yang cenderung dituturkan oleh semua penutur di TP-3 dan TP-4.

Pada medan makna rumah dan bagianbagiannya, gejala onomasiologis ditemukan pada gloss 'dapur' yang ditandai dengan leksikon [pədajan] di TP-1 dan TP-2 serta leksikon [pawon] di TP-3 dan TP-4.

Pada medan makna peralatan dan perlengkapan, gejala onomasiologis ditemukan pada gloss 'gayung' yang ditandai dengan leksikon [siwur] untuk mewakili TP-1 dan TP-3, leksikon [cant ${ }^{\mathrm{h}} \mathrm{up}$ ] untuk mewakili TP-2, dan leksikon [ciduk] untuk mewakili TP-4.

Pada medan makna makanan dan minuman, gejala onomasiologis ditemukan pada gloss 'kerak' yang ditandai dengan leksikon [kəron] di TP-1, leksikon [inti ${ }^{\mathrm{h}} \mathrm{p}$ ] di TP-2, leksikon [kərak] di TP-3, dan leksikon [g ${ }^{\text {hakin] }}$ di TP-4.

Pada medan makna tumbuh-tumbuhan, buah, dan hasil olahannya, gejala onomasiologis ditemukan pada gloss 'ubi kayu' yang ditandai dengan leksikon [ $\mathrm{b}^{\mathrm{h}}$ oled] di TP-1 dan TP-4 dan leksikon [budin] di TP-2 dan TP-3.

Pada medan makna hewan dan bagianbagiannya, gejala onomasiologis ditemukan pada gloss 'kelelawar' yang ditandai dengan leksikon [kampret] di TP-1, [kalıy] di TP-2, dan [lawa] di TP-3 dan TP-4.

Pada medan makna waktu, musim, keadaan alam, dan arah, gejala onomasiologis ditemukan pada gloss 'datar' yang ditandai dengan leksikon [ləmpəy] di TP-1 dan TP-3 dan leksikon [ləncəり] di TP-2 dan TP-4.

Pada medan makna gerak dan kerja, gejala onomasiologis ditemukan pada gloss 'membakar (sampah)' ditamdai dengan leksikon 
[mblədug] di TP-1 dan TP-3, leksikon [ $\eta \mathrm{b}^{\mathrm{h}} \mathrm{h}$ ]] di TP-2, dan leksikon [nuwuh] di TP-4.

Pada medan makna perangai, sifat, dan warna, gejala onomasiologis ditemukan pada gloss 'tajam' ditandai oleh leksikon [landəop] di TP-1 dan TP-4, leksikon [lancip] di TP-2 serta leksikon [pasah] di TP-3.

Pada medan makna penyakit, gejala onomasiologis ditemukan pada gloss 'borok' yang ditandai dengan leksikon [ $\mathrm{b}^{\mathrm{h}} \mathrm{r}$ rok] di TP-1, leksikon [gudig] di TP-2, leksikon [ $\mathrm{t}^{\mathrm{h}} \mathrm{t}^{\mathrm{h}}$ ər] di TP3 dan leksikon [tzpэk] di TP-4.

Pada medan makna pakaian dan perhiasan, gejala onomasiologis ditemukan pada gloss 'anting-anting' ditandai dengan leksikon [antin] [antin] di TP-1 dan TP-2 dan leksikon [suwəy] di TP-3 dan TP-4.

Pada medan makna pakaian dan perhiasan, gejala onomasiologis ditemukan pada gloss 'sangat' yang ditandai dengan leksikon [bayət] di TP-1 dan TP-2 serta leksikon [pisan] di TP-3 dan TP-4.

\section{Semasiologis}

Gejala semasiologis ditemukan pada medan makna (1) makanan dan minuman, (2) tumbuh-tumbuhan, buah, dan hasil olahannya, (3) waktu, musim, keadaan alam, dan arah, (4) gerak dan kerja, serta (5) perangai, sifat, dan warna.

1) Pada medan makna makanan dan minuman, gejala semasiologis ditemukan pada berian atau leksikon [ghakin], yang digunakan untuk menandai tiga gloss yang berbeda, yaitu gloss 'kerak' di TP-4, 'nasi basi' di TP-3, dan gloss 'nasi kering di TP-1 dan TP-2.

2) Pada medan makna tumbuh-tumbuhan, buah, dan hasil olahannya, gejala semasiologis ditemukan pada berian atau leksikon [1วmbək] yang digunakan untuk menandai dua gloss yang berbeda, yaitu gloss 'cabai merah' dan gloss 'cabai rawit' di TP-3.
3) Pada medan makna waktu, musim, keadaan alam, dan arah, gejala semasiologis ditemukan pada leksikon [kəb ${ }^{\text {hul }}$ ] yang digunakan untuk menandai dua gloss yang berbeda, yaitu gloss 'asap' di TP-1 dan gloss 'debu' di TP-2.

4) Pada medan makna gerak dan kerja, gejala semasiologis ditemukan pada leksikon [tani] yang digunakan untuk menandai dua gloss yang berbeda, yaitu gloss "bangun dari duduk' di TP-1 dan TP-2 dan gloss 'bangun dari tidur' di TP-3 dan TP-4.

5) Pada medan makna perangai, sifat, dan warna, gejala semasiologis ditemukan pada leksikon [pasah] yang digunakan untuk menandai gloss 'tajam' dan gloss 'manjur' di TP-3.

\section{Contoh Pemetaan Fonologi dan Leksikon}

\section{Bahasa Jawa di Kabupaten Cilacap}

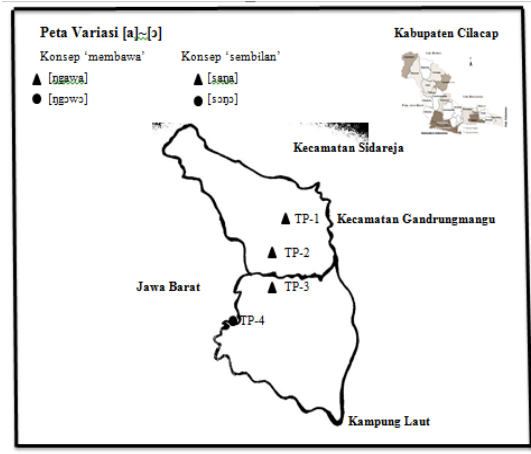

Gambar 1

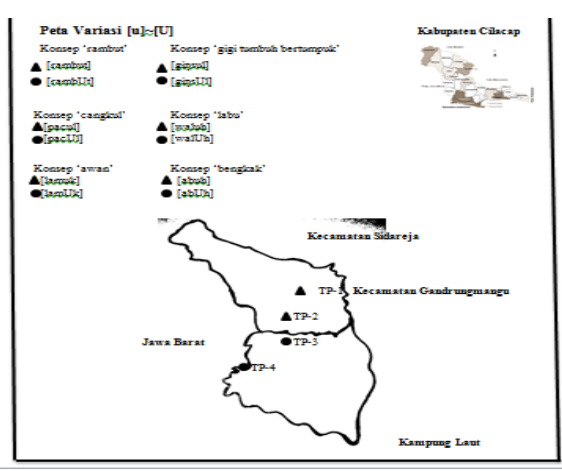

Gambar 2 
Gambar di atas merupakan contoh
pemetaan fonem vokal bahasa Jawa di

Kabupaten Cilacap. Berdasarkan peta variasi vokal [a] [ग] pada gambar 1 dapat digambarkan bahwa konsep 'membawa' dan 'sembilan' dituturkan menjadi dua, yaitu tuturan [ngawa] dan [ngJw)] serta [sanga] dan [sวyว]. Tuturan [ngawa] dan [sanga] dituturkan di TP-1, TP-2,

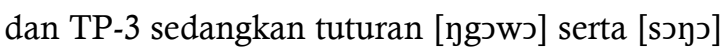
dituturkan di TP-4.

Berdasarkan peta variasi vokal $[\mathrm{u}] \sim[\mathrm{U}]$ pada gambar 2 dapat digambarkan bahwa konsep 'rambut', 'gigi yang tumbuh bertumpuk', 'cangkul', 'labu', 'awan', dan 'bengkak' masingmasing konsep tersebut dituturkan menjadi dua tuturan, yaitu tuturan [rambut] dan [rambUt], [ginsul] dan [ginsU1], [pacul] dan [pacUl], [waluh] dan [walUh], [lamuk] dan [lamUk], serta [abuh] dan [abUh]. Tuturan [rambut], [ginsul], [pacul], [waluh], [lamuk], dan [abuh] dituturkan di TP-1 dan TP-2 sementara tuturan [rambUt], [ginsU1], [pacU1], [walUh], [lamUk], dan [abUh] dituturkan di TP-3 dan TP-4.

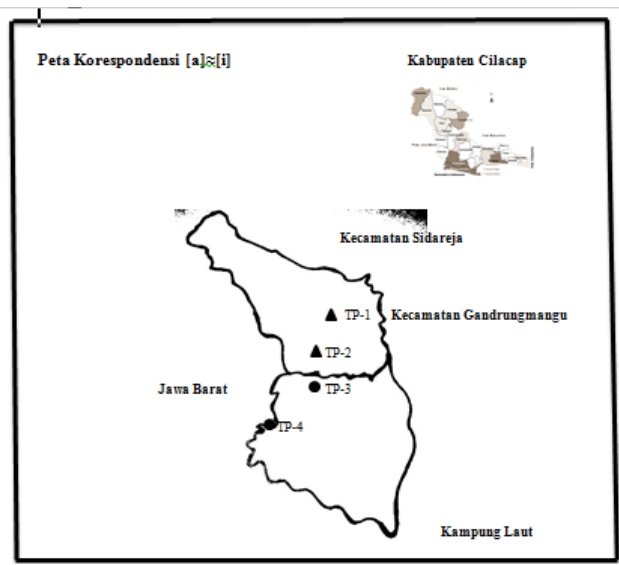

Gambar 3

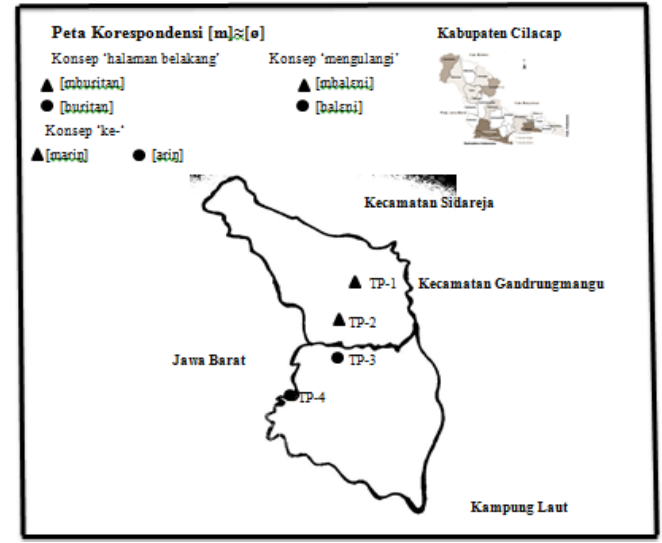

Gambar 4

Gambar 3 merupakan peta korespondensi vokal [a] $\approx$ ii]. Melalui peta tersebut dapat digambarkan bahwa konsep 'di atas', ‘di bawah', 'di belakang', 'di tengah', 'di sana', dan 'di sini' dituturkan menjadi dua tuturan, yaitu [nay] [nḍuwur] dan [nin] [nḍuwur], [nay] [nisər] dan [nin] [yisər], [nay] [mburi] dan [nip] [buri],

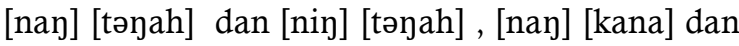

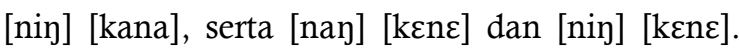
Tuturan [nay] [nḍuwur], [nay] [nisor], [nay] [mburi], [nay] [təyah], [nay] [kana], dan [nay] [kenc] dituturkan di TP-1 dan TP-2 sementara tuturan [nin] [nḍuwur], [nin] [nisor], [nin] [buri],

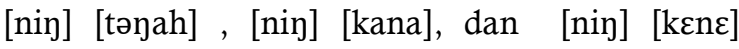
dituturkan di TP-3 dan TP-4. Pada tuturantuturan tersebut dapat dilihat bahwa penutur di TP-1 dan TP-2 cenderung menuturkan kata depan 'di-' dengan tuturan [nan] sedangkan tuturan [nin] cenderung dituturkan semua penutur di TP-3 dan TP-4.

Pada gambar 4 yang merupakan peta korespondensi, dapat tergambarkan bahwa konsep 'halaman belakang','mengulangi', dan 'ke-' dituturkan menjadi dua tuturan, yaitu [mburitan] dan [buritan], [mbaleni] dan [baleni], serta [marin] dan [arin]. Tuturan [mburitan], [mbaleni] dan [marin] dituturkan di TP-1 dan TP- 
2 sementara tuturan [buritan], [baleni] dan [arin] dituturkan di TP-3, dan tuturan [ghakin] dituturkan di TP-3 dan TP-4. dituturkan di TP-4.

Contoh pemetaan leksikon pada gloss yang memiliki gejala onomasiologis

Contoh pemetaan leksikon pada berian yang memiliki gejala semasiologis

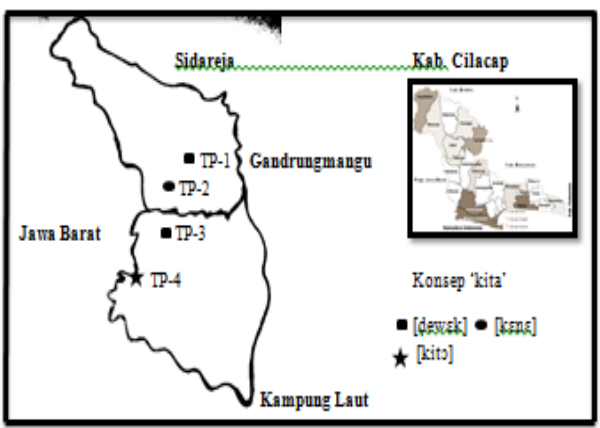

Gambar 5

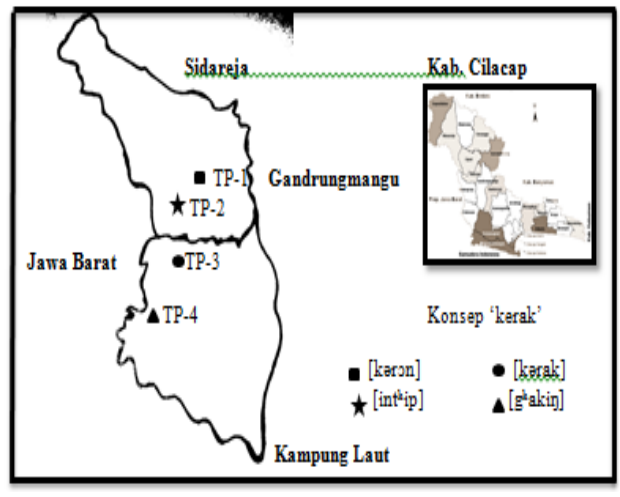

Gambar 6

Gambar 5 merupakan peta leksikon, yaitu gejala onomasiologis pada konsep 'kita'. menggambarkan bahwa konsep 'kita' mempunyai

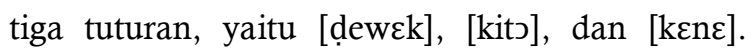
Tuturan [dewek] dituturkan di TP-1, TP-3, tuturan [kito] dituturkan di TP-2 dan tuturan

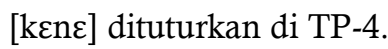

Pada gambar 6 menggambarkan bahwa konsep 'kerak' dituturkan menjadi empat, yaitu

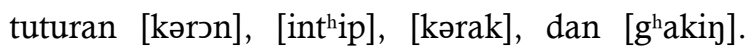
Tuturan [kərən] dituturkan di TP-1, tuturan [inthip] dituturkan di TP-2, tuturan [kərak]

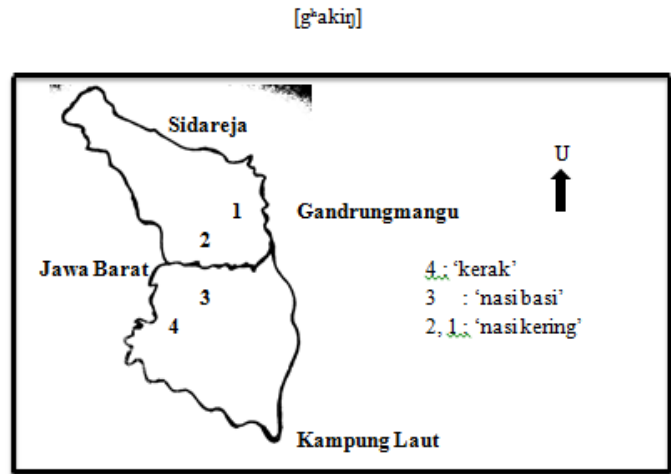

Gambar 7

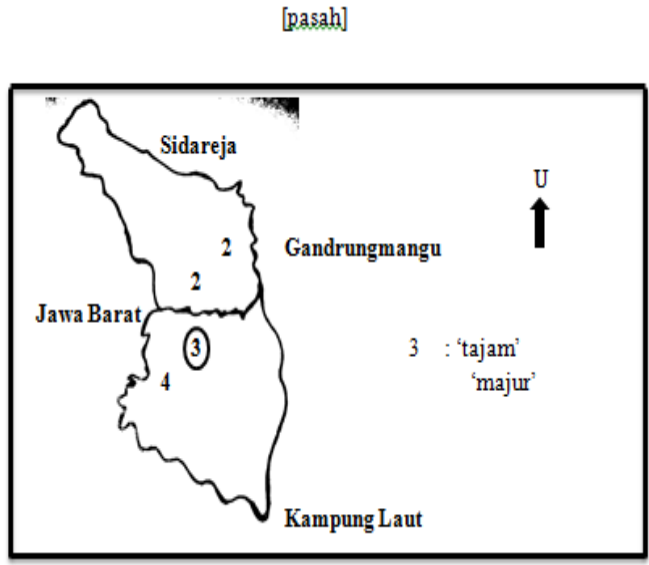

\section{Gambar 8}

Gambar 7 merupakan sampel peta leksikon [ghakin] yang menggambarkan gejala semasiologis, yaitu pemberian nama yang sama untuk beberapa konsep yang berbeda. Melalui peta tersebut dapat dilihat bahwa leksikon [ghakin] digunakan untuk menandai beberapa konsep, yaitu konsep 'nasi kering' di TP-1 dan TP-2, konsep 'nasi basi' di TP-3 serta konsep 'kerak' di TP-4.

Gambar 8 merupakan sampel peta leksikon [pasah]. Berdasarkan peta tersebut 
dapat digambarkan bahwa leksikon [pasah] digunakan untuk menandai dua konsep, yaitu konsep ‘tajam' dan konsep 'manjur' di TP-3.

\section{SIMPULAN}

Berdasarkan hasil analisis data tersebut dapat disimpulkan bahwa BJC memiliki beragam variasi, yaitu meliputi: variasi fonologi yang berupa variasi bunyi vokal, variasi bunyi konsonan, korespondensi bunyi vokal, dan koresponensi bunyi konsonan. Variasi bunyi vokal dalam BJC berjumlah 23, di antaranya variasi $[\mathrm{a}] \sim[\mathrm{J}],[\mathrm{i}] \sim[\mathrm{a}],[\mathrm{i}] \sim[\mathrm{e}],[\mathrm{I}] \sim[\mathrm{i}],[\mathrm{u}] \sim[\mathrm{U}]$, $[\mathrm{e}] \sim[\varepsilon], \quad[\varepsilon] \sim[\varnothing],[\varepsilon] \sim[\mathrm{a}],[\varepsilon] \sim[\mathrm{e}],[\varepsilon] \sim[\mathrm{i}],[\varepsilon] \sim[\supset]$ $[ə] \sim[\varnothing],[ə] \sim[\mathrm{a}],[ə] \sim[\mathrm{i}],[\partial] \sim[\mathrm{u}],[\mathrm{o}] \sim[\mathrm{u}],[\mathrm{o}] \sim[\supset]$, [ว] [a], [ว] [u], [ø] [a], [ø] [i], [ø] [ə], dan $[\varnothing] \sim[\mathrm{u}]$. Variasi bunyi konsonan berjumlah 16, meliputi variasi $[\mathrm{r}] \sim[\mathrm{d}],[\mathrm{d}] \sim[\mathrm{j}],[\varnothing] \sim[?],[\mathrm{w}] \sim[\varnothing]$, $[\mathrm{b}] \sim[\varnothing], \quad[\mathrm{k}] \sim[\varnothing], \quad[\mathrm{k}] \sim[\mathrm{n}], \quad[\mathrm{m}] \sim[\varnothing], \quad[\mathrm{m}] \sim[\mathrm{p}]$, $[\mathrm{g}] \sim[\mathrm{k}],[\mathrm{k}] \sim[\mathrm{t}],[\varnothing] \sim[\mathrm{n}],[\mathrm{r}] \sim[\mathrm{g}],[\mathrm{k}] \sim[\mathrm{n}],[1] \sim[\varnothing]$, dan $[\mathrm{b}] \sim[\mathrm{m}]$. Sementara itu ditemukan juga kaidah korespondensi bunyi vokal berjumlah 5, meliputi korespondensi $[\mathrm{u}] \sim[\mathrm{U}],[\varepsilon] \sim[\mathrm{e}],[\mathrm{o}] \sim[\mathrm{J}]$, [a] [i], dan [a] [ว], $\quad$ serta 1 kaidah korespondensi bunyi konsonan, yaitu korespondensi $[\mathrm{m}] \sim[\varnothing]$.

Selain variasi fonologi, BJC juga memiliki variasi leksikon, yaitu gejala onomasiologis dan semasiologis pada medan makna tertentu. Variasi-variasi tersebut kemudian dipetakan dalam contoh peta bahasa yang telah dijelaskan pada bab sebelumnya. Munculnya variasi fonologi dan leksikon dalam BJC disebabkan oleh letak geografis daerah pengamatan yang berbatasan dengan Kabupaten Pangandaran, Jawa Barat. Kontak bahasa antarpenutur di masing-masing titik pengamatan atau antara penutur di titik pengamatan satu dengan titik pengamatan lainnya serta tingkat pengetahuan dan pendidikan penutur juga menjadi faktor penyebab terjadinya variasi bahasa Jawa di Kabupaten Cilacap, khususnya di wilayah yang berbatasan dengan Provinsi Jawa Barat.

Penelitian variasi bahasa Jawa di Kabupaten Cilacap dapat dikembangkan lebih lanjut lagi, misalnya apabila penelitian tersebut masih dalam lingkup kajian geografi dialek, dapat diteliti dengan perhitungan menggunakan dialektometri. Penelitian variasi bahasa Jawa di Kabupaten Cilacap juga dapat dikaji menggunakan kajian sosiodialektologi serta diteliti pada tataran yang lain, misalnya variasi bahasa Jawa di Kabupaten Cilacap pada tataran morfologi, sintaksis, atau semantik.

\section{DAFTAR PUSTAKA}

Andini, Hanifah. (2017). "Makna Kultural dalam Leksikon Perlengkapan Seni Begalan Masyarakat Desa Selakambang Kecamatan Kaligondang Kabupaten Purbalingga”. Jurnal Sastra Indonesia Universitas Negeri Semarang.

Antono, Arif. (2019). "Pemertahanan Fonologis dan Leksikal Bahasa Jawa di Kabupaten Wonogiri: Kajian Geografi Dialek". Jurnal Sastra Indonesia Universitas Negeri Semarang.

Chaer, Abdul. (2007). Kajian Bahasa : Struktur Internal, Pemakaian dan Pemelajaran. Jakarta: Rineka Cipta.

Hastuti, Puji Anisa. (2018). "Pemakaian Fonologi dan Leksikon Bahasa Jawa: Studi Sosiodialektologi di Kabupaten Batang". Jurnal Sastra Indonesia Universitas Negeri Semarang.

Ningtyas, Suyanto dan Tiani. (2017). "Inovasi Fonetis pada Kantung Sunda di Wilayah Kecamatan Wanareja, Kabupaten Cilacap". Jurnal Laras, Universitas Diponegoro.

Rosyadi, Diding. (2017). "Perbandingan Leksikon Bahasa Jawa dengan Bahasa Sunda di Kecamatan Larangan Kabupaten Brebes". Jurnal Sastra Indonesia Universitas Negeri Semarang.

Sari, Maliana Devita. (2018). Nilai Filosofis dalam Leksikon Batik Demak di Kabupaten Demak (Kajian Etnolinguistik). Jurnal Sastra Indonesia Universitas Negeri Semarang.

Sudaryanto. (2015). Metode dan Aneka Teknik Analisis Bahasa: Pengantar Penelitian Wahana Kebudayaan Secara Linguistis. Yogyakarta: Sanata Dharma University Press.

Sumarlam, dkk. (2012). Pelangi Nusantara: Kajian Berbagai Variasi Bahasa. Yogyakarta: Graha Ilmu.

Zulaeha, Ida. (2010). Dialektologi: Dialek Geografi dan Dialek Sosial. Yogyakarta: Graha Ilmu. 